\title{
THE TALLINN DEPARTMENT OF THE ESTONIAN NATIONAL MUSEUM: HISTORY AND DEVELOPMENTS
}

\section{Piret Õunapuu}

\begin{abstract}
The Estonian National Museum (ENM), established in 1909 in Tartu, developed quickly and comprised a large membership in the country - the members living in Tallinn were active in heritage collection and awareness-raising activities, and formed a separate department which gradually gained independence. As an inevitable outcome, the Tallinn Department finally separated from the parent museum. Despite organisational difficulties and political circumstances, the department managed to supplement collections and arrange spectacular events. In 1919, the Tallinn Department of the ENM became an independent Estonian Museum Society in Tallinn, i.e. the Estonian Museum in Tallinn, which, in the course of time, became more inclined toward art and developed into the Art Museum of Estonia.
\end{abstract}

Key words: antiquities, Art Museum of Estonia, Estonian National Museum, folk art, folk culture, German occupation 1917-1918, heather - the museum flower, heritage, lottery, museum parties, open-air museum

\section{INTRODUCTION}

In this article I attempt to provide an overview of how the Tallinn Department of the Estonian National Museum was formed, which in turn evolved into the Estonian Museum Society in Tallinn ${ }^{1}$ and this, in turn, became the Art Museum of Estonia. The fact that both museums have also dealt with their history, associated with the anniversaries, yet have not underlined the explicit connection between these two substantial memory institutions of Estonia, has been the direct reason for writing this article. ${ }^{2}$ At present, both museums focus on distinct subject matter and are not competitors in devising collections or in communication with the public. Ninety years ago, however, things were different and the separation of the Estonian Museum in Tallinn, from the Estonian National Museum in Tartu, was a long and painful process.

The material, kept primarily in the archive of the Estonian National Museum, serves as a basis for the article, whereas the sources used most encompass the diverse loose-leaf material concerning the Tallinn Department of the 


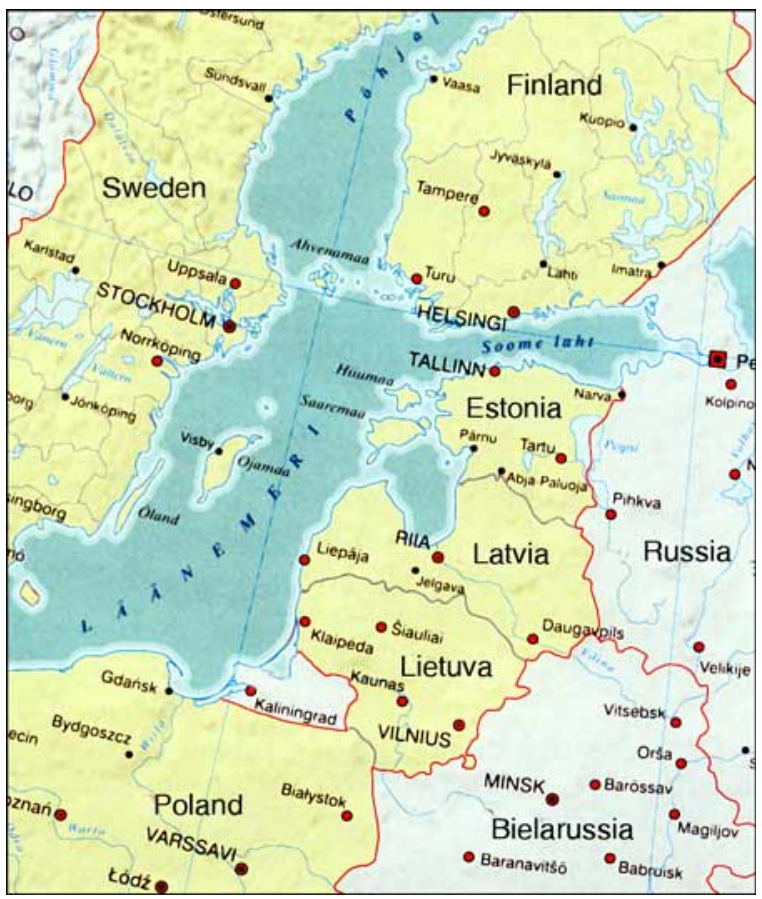

Figure 1. Map of Estonia and neighbouring countries.

Estonian National Museum 1919-1920. The hand-written memories of one of the key figures of the quondam events, August Pulst ${ }^{3}$, are located in the archive of the Art Museum of Estonia, as well as in that of the Estonian National Museum (ENM). Content-wise, this is actually a manuscript of the memories, the initial variant of which is a hand-written draft version, written during the period 1943-1948 and titled The Estonian Museum in Tallinn. Historical data, with abundant corrections and additions (Pulst 1948). The typescript text from 1973, My work in connection with folk art - ethnography, preserved in the ENM, is a more succinct summary written on the basis of the former version (Pulst 1973). Likewise, I have also used the unpublished article by Heini Paas from 2004, entitled About the history of the Estonian Art Museums 1919-1944. Earlier, the same author has published an article About the history of the Estonian State Art Museum, the establishment and history of the museum 19191940" (Paas 1980). However, the earliest and most immediate insight in the subject matter is the article by Bernhard Linde, The development of the idea of the Art Museum of Estonia, and the Estonian Museum Society in Tallinn (Linde 1931).

With regard to the ENM, the establishment of the Tallinn Department is covered in a relatively short overview published in the jubilee edition of the 
Estonian National Museum, 100 Years of the Estonian National Museum (Õunapuu 2009). August Pulst's activities in the Tallinn Department of the ENM, and later in the Tallinn Estonian Museum are outlined in the ENM series of publications of diaries written by heritage collectors (Õnapuu 2006).

\section{THE FIRST YEARS OF THE ESTONIAN NATIONAL MUSEUM}

The process of creating the Estonian National Museum (established in 1909) had been long and cumbersome. What had so far been merely the cherished idea of some enthusiasts - the Estonian museum - now obtained a dignified name - the Estonian National Museum (in Estonian: Eesti Rahva Muuseum, literally: the Museum of Estonian People). At this point it is expedient to dwell upon the selection of the name for the museum. First and foremost, the museum was established to serve as the repository for Jakob Hurt's folklore collections. Indeed, a decision was made at the meeting convened after the funeral of Jakob Hurt, to initiate the Hurt museum, however, quite soon a more comprehensive name - Eesti Rahva Muuseum (Estonian National Museum) was selected to be appropriate and in concord with the increasing amount of relevant work (Leinbock 1934: 4-5). Naturally, it was the forward-looking intelligentsia who primarily realised the significance of the museum in the cultural context.

Collection work was the main aim during the first years. The phenomenon, that the museum, mainly relying on non-remunerated labour force, people who were voluntarily working for their homeland, set a goal to collect as much heritage as possible from all over Estonia, parish by parish, and managed to send dozens and dozens of people to do this work, is unique in the world. The outcome comprised abundant and valuable collections of artefacts stored in the museum prior to the devastating World War I (Õunapuu 2007: 11).

\section{THE STIMULUS FOR SETTING UP THE TALLINN DEPARTMENT}

However, the outburst of World War I had a profound impact on heritage collection for the forthcoming years. The authorities and rural people suspected those collecting the antiquities of espionage and unfamiliar persons walking from village to village seemed suspicious. Thus, the number of collectors decreased - only six people were doing this job in 1915, one of them August Pulst, a student at the Art School of Riga, who continued with what he had started the year before in his home parish Tori. 
The launch of the Tallinn Department of the Estonian National Museum was initiated because of warfare, with the young heritage collector August Pulst in charge. After his 1915 collection trip to Tori parish, Pulst had not managed to send the objects to Tartu, because of the circumstances of war, and instead, he had travelled with them to Tallinn. There, he displayed the artefacts at the exhibition of the Estonian Agricultural Society (August 29 - September 1), under the title Estonian National Museum. The 1915 collection and antiquities from Tori, Pärnu County (Matto 1916: 18). The person who facilitated Pulst's participation at the display was Mihkel Aitsam, fiduciary of the ENM and an instructor at the Tallinn section of the Estonian Farmers' Society (Pulst 1948: 4).

I got to Tallinn before the opening of the exhibition of the Farmers' Society. I was given a space to display the Tori collection in the "rotunda" of the large pavilion. It was a big surprise-enormous interest in the antiquities from Tori. A lot of presents, a full set of a female funeral costume from Hiiu island, and other objects. Among those who approached me and introduced themselves were Hans Laipmann, veterinary K. Saral, lawyer Oldekop, journalist H. Prants and others. Approximately 30,000 people visited the exhibition within a couple of days. A contact was created with the people in Tallinn. (Pulst 1973: 8-9)

The popularity of antiquities at the exhibition provided an opportunity to display and introduce the objects for a longer period of time. August Pulst displayed some of the artefacts in an apartment at Vladimiri Street 24/4, Tallinn, and published a relevant announcement in the Päevaleht newspaper:

Who of us is not interested in our folk costumes and patterns! I thinkeveryone! But have we looked at them in detail, cast a glance to the depth and tastefulness of the mind of those who created these items? That's what it is - we haven't. This is why it is my wish and request: have a look at them once more. Examine them and do not disturb others doing the same. Let us know about the places where something similar can be found and make it possible to look at these "golden treasures" together. The foundation and organisation for all this is already there. (Pulst 1915a)

The apartment was in the ownership of the well-known esperantist of the time, Jakob Rosenberg, A. Pulst was a fellow tenant. The number of those visiting the display was around 50 and Pulst made copies of the patterns for those who wished them. Together with photographer Peeter Parikas, he arranged the photographing of the people dressed in collected folk costumes. In the later phase, Pulst tinted the photos and Parikas sold the pictures, however 
Pulst has subsequently admitted the inevitable inaccuracy of this undertaking (Pulst 1973: 9). The sets of folk costumes were not complete and in some occasions, even combined items from different localities.

This successful undertaking enthused August Pulst to promote the subject matter on a wider scale - a special issue of the magazine Tallinna Kaja was dedicated to antiquities and the promotion of the museum ${ }^{4}$, whereas the relevant information was mainly written by August Pulst himself. In addition, the magazine issue was illustrated with pictures of his collection trips and folk costumes, altogether 12 photos of garments, some of them taken during the collection trip and some photographed by P. Parikas. Pulst's magazine articles - being a very poetic panegyric to Estonian folk art - had a motto that education, culture and arts are the bearers of a nation (Pulst 1915b: 725-726).

\section{AN IDEA TO HAVE A SEPARATE DEPARTMENT}

Pulst, having graduated from the Art School in Riga, worked at the time as a decorator and stage painter at Estonia, the national opera and ballet theatre. His first job in the theatre was August Kitzberg's Werewolf, and he was deeply involved in the process. Pulst writes in his memories that in addition to the construction of props, he was also engaged in dress-making, setting the folk dance and teaching how to howl like a wolf:

I understood that there was a vital need here for different museum elements - you had to know how to apply them in action. It became extremely evident how the collections of antiquities of our nation are inevitably necessary for Tallinn in the creative work and that there was a great need for an Estonian museum. This is why I assumed the task to establish an Estonian museum here in Tallinn. And as it was hardly feasible, under the circumstances of war, to launch an independent museum in Tallinn, I became fully devoted to the idea to establish the Tallinn Department of the Estonian National Museum here. From that time onwards, I started with preliminary work in this direction. (Pulst 1948: 6)

A. Pulst's active involvement had indeed increased an interest in the museum. Bearing in mind this goal, Pulst and Rudolf Hurt, board member of the ENM, decided to ask those interested in the museum, i.e. the trustees and members of the ENM in Tallinn, to a meeting to discuss the relevant development activities in Tallinn. The meeting took place on 2 December 1915, in the premises of the Kindergarten Society, at Viruvärava Puiestee 23, and from among the 15 invited persons, the following people turned up: Rudolf Hurt, Mihkel Aitsam, 
Karl Saral, Aleksander Mohrfeldt, Ado Birk, August Busch, Nikolai Kõll, Hans Laipmann and August Pulst. The latter said in his speech:

Tallinn is not a village where we could collect the antiquities and move on. Tallinn is a city. There has to be a museum here, or a representation of the museum where to display the collections and to where the visitors would bring artefacts. I make a proposal to establish a Department of the Estonian National Museum in Tallinn! (Pulst 1948: 9)

Pulst's suggestion was adopted unanimously and he was given a mandate to pass the decision on to the ENM. On 13 January 1916, E. Eisenschmidt responded to the notice:

Decisions are indeed very good in case they are implemented. The supervisory board of the museum has not yet discussed the question regarding the Tallinn Department. Anyway, it is probably the full assembly of the Museum that will make this decision and commence with the relevant amendments of the statues. (Pulst 1973: 10)

Thus the idea of creating a separate department began to germinate.

Pursuant to the minutes of the ENM, the purport of Tallinn Department was first discussed at the board meeting on 23 January 1916 - a decision was made to propose the full assembly of active members with the following issue: c) when and how could it be possible to also open the departments of the ENM in other towns. (Suggested by Tallinn memebrs - A. Pulst) (Minutes II: 279). Next time, the relevant issue was discussed lengthily at the meeting of the board and the heads of working groups of the ENM, on 18 February 1916, between the convened Oskar Kallas, Karl Eduard Sööt, August Jõudu, Gustav Matto, Alma Johanson, Villem Ernits and Edgar Eisenschmidt. The minutes of the discussion report:

By now, after a relevant inquiry, we have received a more reliable notice from August Pulst about the establishment of the Tallinn Department of the E. N. Museum. Namely, the meeting of the Tallinn-based board members of the museum, trustees and heritage collectors was held on 2 December 1915, initiated by A. Pulst, and the decision was made: a) To start with large-scale systematic heritage collection in Tallinn, and for this purpose b) To obtain the permission of the local governor and military head. c) To establish the E. N. Museum in Tallinn and make a relevant proposal to the Museum government. d) To ask premises from the Town Government for the collection of antiquities or the future department, where to display artefacts for the public and organise exhibitions, e.g., on Old Tallinn and military weaponry. e) The artefacts collected in 
Tallinn would temporarily stay in the Tallinn Department. Having contemplated the proposal to establish the department, a decision was reached that Statutes of the [Estonian National] Museum do not allow to create an independent department, and moreover, the creation of such a department would fragment the power of the Museum, because it is important that we have at least one comprehensive Museum; still, we are of the opinion that local collection work could be largely inspired by local exhibitions of antiquities, which in some towns of our homeland could stay as permanent displays if local people wish to organise this and form into a specific working group for the collection of artefacts. (Minutes II: 281283)

As seen from the above, the issue of Tallinn Department was also an incentive to discuss the relevant problem more broadly, not only with the focus on either Tartu or Tallinn.

The highest governing body of the Estonian National Museum - the general assembly of members and active members - held a meeting on 19 February 1916, with more than 100 participants. Referring to the proposals made earlier in Tallinn and Viljandi, the following decisions were made during the gathering:

1) to instigate heritage collection at the local level, the Museum is ready to form local working groups; 2) the artefacts collected by the local working group are the possession of the Museum, however, they may be kept in the location of collection for some time as a permanent exhibition. The list of collected artefacts has to be sent to the Museum; 3) the Museum is ready to send doublets to permanent exhibitions, particularly of the objects that have been collected in the locality of the exhibition, likewise, the Museum would also set up the display of other artefacts in different places, should this be necessary; 4) it is recommendable, in places where there is a wish to set up a permanent exhibition, to raise money on the spot to cover the costs of collecting, and other expenses; if possible, the Museum would provide financial support for the organisation of exhibitions. It is not recommended to open independent departments as this would fragment the collections too much and complicate research. The opening of local exhibitions would hopefully bring in more new members. In Tallinn, there is hope to organise such an exhibition quite soon, steps have been taken to obtain relevant premises from the town government. (Minutes II: 291)

As becomes evident from the minutes, this meeting did not adopt an affirmative decision to establish the Tallinn Department, and the participants did not 
applaud this, as A. Pulst repeatedly refers to in his memoirs. The situation was quite the contrary.

As a response to the situation, on 19 March A. Pulst notified the joint meeting of the ENM board and the heritage collection working group, that several Tallinn-located members of the museum have suggested to convene a general assembly of the museum, bearing in mind that such a meeting in Tallinn would indeed be an impetus for the museum idea and make it more viable. As such a meeting would require proper preparation, it was thought that it was better to make an attempt to hold the gathering in autumn, and a relevant suggestion was proposed to the Tallinn members (Minutes II: 301-302). However, the general assembly did not take place in Tallinn in the autumn of 1916.

In reality, the museum-related activities in wartime Tallinn were mainly initiated by August Pulst. It was difficult to find rooms and if possible, some of the artefacts located in Tallinn were sent further to Tartu. The search for premises was still ongoing. In 1916, when Pulst worked in the Estonia Theatre as a decorator, he first placed the artefacts in his storeroom of paints. Pulst writes in his memoirs:

I took advantage of the situation - I de-cluttered the storage room of paints, it is a room without a window, with surface area of $1 \times 4$ metres, and I moved my Tori collection there, from Vladimiri Street 24. So, from a wooden house into a stone building. The artefacts remained there until the opening of the Museum Department in 1918. Thus, by the end of 1916, I had managed to send the majority of the Tori collection to the E. N. Museum, and, in addition, a lot of printed products from Tallinn. (Pulst 1973: 11)

Pulst's life and work in the Estonia Theatre also facilitated the collection of artefacts. In the rear of the theatre there was a market place in Tallinn, where rural people came to trade. For a heritage collector, this was a real goldmine. A. Pulst looked out of his window and when he spotted an exquisite blanket on a farmer's horse-wagon or sleigh, he would rush outside to make the bargain purchase. Pulst notes that he had actually learnt the trick - to exchange the antiquities of the farmers who had come to the town, for a new object or money - from Ants Laikmaa (Pulst 1948: 5).

In connection with the idea of creating a separate department, the number of the Tallinn-based members of the ENM increased from 83 to 166 during 1916 (Pulst 1973: 11), one of their tasks was to represent the ENM at the agricultural exhibitions in Tallinn. Museum artefacts from Tartu, and also contemporary handicraft made after old examples were sent from Tartu to be displayed at agricultural exhibitions, with a practical goal, in addition to the promotion of heritage - to find resources for the operation of the museum. 
The selling of heather branches was one of the main ways of procuring funds for the museum. It was quite by chance that the heather became the flower of the Estonian National Museum; due to practical reasons, it was necessary to find a beautiful and enduring plant that could be easily made into bunches and that would be in full blossom during fieldwork in the autumn. Likewise, it was also relevant that the flower would be easily available in large quantities. Young girls from upper secondary schools were the ones who mainly picked the heather and arranged it in nice bunches.

\section{ABOUT THE NECESSITY OF THE TALLINN DEPARTMENT}

The years of war and revolution passed relatively quietly and not much was undertaken in Tallinn. In addition to his engagement in the Estonia Theatre, August Pulst was also working as a full-time drawing teacher in the Lender High School for Girls, this leaving little time for museum affairs. As of autumn 1916, he became a conscript and worked in an office in Tallinn, while he continued painting props at night (Pulst 1973:12). Inevitably, the museum related work was put aside, apart from the collection of some printed materials from publishing houses.

Yet at the time, the feasibility and need for establishing a museum department was discussed in Tartu - on 11 February 1917, the general annual meeting of the ENM members and active members was convened, the minutes of the event reflect the following:

In order to promote and fecund the collections of the Museum outside Tartu, it is considered recommended to organise permanent and temporary exhibitions. It would be particularly necessary to open a permanent exhibition or department in Tallinn where the Museum collections, and their taking into practical life, would probably fall into good soil, for example, in the Arts and Crafts School. This issue has already been discussed earlier and considered to be recommendable. The meeting admits all these intentions to be necessary. During the negotiations, it is also recommended to promote the Museum activities, particularly in St. Petersburg. (Minutes II: 374)

August Pulst, a trustee of the ENM in Tallinn, took the floor during the abovementioned meeting, and announced that the town government of Tallinn was willing to provide premises for museum collections should there be a wish to establish a permanent exhibition in Tallinn. This idea, to open a permanent exhibition in Tallinn was unanimously approved by the meeting (Minutes II: 375-376). 
The ENM members from Tallinn and Tartu organised a joint event - an educational meeting conducted in Tallinn on 5 March 1917, where Kristjan Raud spoke about the crafts of English homes and Voldemar Päts focused on the craftwork of Estonian people. The Tartu-based ENM members were represented by spokesman E. Eisenschmidt (Minutes II: 358).

With an aim to enliven the relevant action, the Tallinn-based trustees and members of the ENM were convened in Tallinn, on 15 April 1918, by way of a letter signed by R. Hurt. The trustees were a separate link between the museum and people. This idea - to have local helpers for the museum - actually originated from the early days of the ENM. The meeting of the heritage collection working group had decided in 1909:

The immediate promoters of the Museum endeavour would be the trustees, requested by the Museum to do the job, scattered as densely as possible all over the country, not only in towns and in every parish but also in rural municipalities and villages. The trustees could be the people in charge of societies, teachers, doctors, chemists, merchants, rural municipality secretaries, etc. The responsibility of the trustees would be to accept donations and transfer these to the closest centres or, if possible, directly to the Museum. (Minutes I: 13)

By the end of 1917, the Estonian National Museum comprised 742 members, and, additionally, 99 life members. Out of the membership, 155 persons and 8 lifelong members were from Tallinn (Estonian National Museum 1918: 60-79).

Meetings were strictly forbidden at the time, relevant permissions were not granted. This might have partially been the reason why the number of participants was extremely small - the ones who came included Kr. Raud, Karl Saral, Hans Kubu, P. Parikas, Heino Vaks and A. Pulst. A decision was made to start the Tallinn Department of the ENM - the approval of the main museum had already been obtained in 1916 - and elect the board, appoint a secretary, rent the premises and immediately commence with the rescue and consolidation of artefacts and open the museum. Hereby a question emerges as to what was the basis for the firm knowledge that the relevant permission had already been granted by the Estonian National Museum, as the minutes of the 1916 meeting do not provide any confirmation in this regard. A. Pulst was appointed to be the secretary with monthly salary of 200 marks. As of September 1, Pulst's salary was increased to 250 marks, and Miss E. Bamberg was hired, at a pay of 1 mark per hour (Minutes 6/1918).

The election of the board was decided to be undertaken during the next meeting. As there were no premises available that could be suitable for the museum, A. Pulst conceded to rent out his studio, located in the concert hall 
side of the Estonia Theatre building, with the surface area of $50 \mathrm{~m}^{2}$ and monthly rental of 25 marks (Pulst 1973: 12-13).

The next meeting, held in the premises of the museum department, was also conducted secretly, without the permission of authorities. The convened participants were as follows: Ebba Saral, P. Parikas, Johannes Parikas, Jaan Rumma, Hans Kubu, Mrs. Anna Kõrv, Miss L. Kõrv, T. Jürgens, Ella Bamberg, E. Lass, Pauline Voolmann, A. Õunapuu, A. Pommer and A. Pulst. The members of the first board were elected: chairman Kr. Raud, secretary K. Saral, treasurer P. Parikas. Besides A. Pulst, Miss Bamberg was also employed. Candidate board members were Miss A. Kõrv and schoolteacher A. Saar. Director Jüri Jaakson and Dr. Aadu Lüüs were appointed as financial controllers (Estonian National Museum 1918: 59).

\section{LAUNCH OF THE DEPARTMENT}

The opening of the Tallinn Department took place on 12 May 1918. The museum was open every day for two hours (12-14). The indispensable fittings semi-glass cabinets - were obtained from the building society of the Estonia Theatre. Board members K. Saral and P. Parikas were present at the opening event, Kr. Raud was absent. The doors were opened and the first person to step in was A. Pulst. In addition, a number of people had gathered for the opening event. The door of the museum was decorated with two headings printed in two different languages on white cardboard: Eesti Rahva Museumi Tallinna Osakond ('Tallinn Department of the Estonian National Museum') and Estnisches National Museum Zveigstelle Reval (Pulst 1973: 13-14).

Soon after the opening of the Museum in the Estonia Theatre building, the procurement of new premises was taken into the agenda of the board meeting. An excerpt from the board meeting from 4 June 1918:

4) the issue of new premises was discussed, the possible sites came into question - - former premises of the catering service on Lai Street, the tower of Kik in de Kök and the premises of Kadriorg Palace. A decision was made to take steps to obtain them. (Minutes 5/1918)

This was the first time when Kadriorg Palace was mentioned in connection with the museum.

The news about the formation of the Tallinn Department and its activities was slow in getting to Tartu. It remains unclear whether this was to do with the complicated war time or mere unwillingness. It was only in June, at the board meeting of the Estonian National Museum when the secretary disclosed that 
some members and trustees of the Museum had convened in Tallinn and adopted a decision to establish a Museum Department in Tallinn to organise collection work and present the collections. It has been decided to appoint a paid secretary and obtain a room in the Estonia Theatre for record management and storage of collections. The idea was approved and it is recommended that the new department would firmly follow the decision made on 19 February 1916, at the general assembly meeting of the Museum, with regard to local working groups for the collection of artefacts and permanent exhibitions. A working group comprising A. Jõudu, Karl Eduard Sööt, J. Mägi and E. Eisenschmidt is elected to work out the relationship with the department and report their results to the general meeting. (Minutes II: 423-424)

The question concerning the financial relationship with the new Tallinn Department emerged in connection with the cash report. Money had been collected for the Tallinn Museum, and had been deposited in the Tallinn Loan and Savings Co-operative (approximately 15,000 roubles). It was decided to present the financial assets of the Tallinn Department in the consolidated financial report of the ENM, under a separate note (Minutes II: 419-420).

On 13 June 1918, the ENM presented the Rules of Procedure to the Tallinn Department, and the document was adopted on the next day, at the general meeting of members and active members. The Rules of Procedure stipulated the following:

1) Estonian National Museum shall establish the Tallinn Department with the purpose to supplement and present the collections of the museum.

2) The collections and the inventory or the Department shall be in the ownership of the Estonian National Museum.

3) To accomplish its tasks, the Department shall be entitled to organise collections, exhibitions, parties, etc. and receive donations in the name of the Museum.

4) The collections of heritage (i.e. folkloristic and cultural history related) shall remain in Tallinn as a permanent exhibition, for a shorter or longer period of time, upon the agreement of the board of the Museum. Collected artefacts shall be registered in Tartu, within the general list of the Museum, with an additional list of records held with regard to the artefacts in Tallinn.

5) 1-2 copies of all printed materials - books, newspapers and archival materials - obtained by way of the Department shall be given to the archival library located in Tartu at the Museum.

6) The Museum shall give its doublets to the Department and, if so requested, shall organise temporary systematic exhibitions of its other collections. 
7) The members of the board and the internal audit committee of the Department shall be elected at the general assembly of the members of the Tallinn Department, of which the E. N. Museum shall be notified. The chairman of the board of the Department is simultaneously the Museum's representative in Tallinn.

8) The Department shall have its own business records, the list of collections, inventory records, cash book, minutes' book, and a record book for the copies of incoming and outgoing letters.

9) The officials of the Department, and if requisite, also the paid officials, shall be invited and elected by the board of the Department.

10) The Department shall operate within the limits of the budget, approved by the general assembly of the Tallinn members, of which the E. N. Museum shall be notified (approve).

11) The board of the Museum shall be entitled to inspect the operation of the Department at any moment of time. The Department, on the other hand, shall annually send its activity reports.

12) The decision with regard to the dissolution of the Department shall be made by the general assembly of the Department by a simple majority vote. (Rules of Procedure)

As becomes evident from the Rules of Procedure, the Tallinn Department actually enjoyed relatively substantial independence in organising its activities, and the Estonian National Museum in Tartu did not consider it necessary to interfere in the issues regarding the management and administration of work. The fact that the collections and the archive form an integral whole is a normal situation in the relationships with the mother institution and a department.

The work and activities of the department were diverse, endeavouring to involve young people. A. Pulst with his inexhaustible museum enthusiasm managed to indeed inspire the young. Thus, a youth circle gathered around the department, altogether seven persons who referred to themselves as museumlased ('museumians'), they all had personal nicknames, for instance, Muuseumieesel ('Museum Donkey), Paberikoi ('Paper Worm'), etc. August Pulst was called Vanamuuseum ('Old Museum') or simply Museum. The young museum friends walked around and collected antiquities, having collection books with them to precisely note down all the artefacts. This fact was also announced in the newspaper:

The collectors of antiquities, dispatched by the museum department, have museum-named collection books with them. Those who do not have this, have nothing to do with the museum department. (Päevaleht $22 \mathrm{Nov}$ 1918) 
German occupation started in February 1918, followed by the destruction of all kinds of revolutionary literature. The Estonian National Museum attempted to collect the material associated with the revolution. An order was issued in Tartu to commence with the rescue of revolution related materials - all kinds of printed matter were collected, such as fliers, etc. In Tallinn, for instance, an attic was cleared of Bolshevik literature. On Thursday nights, the young museumians gathered at A. Pulst's place, around a red-light electric bulb to tell ancient stories - this was the reward for their collection work (Pulst 1973: 14). All these undertakings did involve a great deal of risk at the time, and could not be allowed according to today's museum education principles. Still, A. Pulst and actor H. Vaks were indeed the two main figures involved in this risky undertaking, rescuing revolutionary materials from incineration in central heating furnaces. The relevant results were extremely good, according to a report of $1918^{5}$ (Activity report). The museum department also established an archival library in Tallinn, upon the initiative and efforts of a young enthusiast J. Tohvelman. By the time the Tallinn Department of the ENM concluded this operation, more than 1000 books and 300 brochures had been collected (Pulst 1973: 18). However, this endeavour had probably not been too consistent as in 1919, the board meeting had decided:

to consider it necessary to establish an archival library at the Museum Department, to collect everything that is published in the Estonian language, and secondly, all literature that concerns Estonians and Estonia, and what has been published in foreign languages in our country. (Minutes 20/1919)

During the next meeting, it was understood that all this could not be accomplished at once, and a principle was introduced: to primarily acquire books which are endangered to become lost and are rare, and the second type are fiction books, and the third type are books of little importance. (Minutes 22/ 1919) The fact as to what kind of books are of little importance, and why, is not further explained.

An important direction in the operation of the museum was to render more wide-based value to heritage. A. Pulst, together with Karel Kitt, a young eager member, organised a museum day in Harku, in the vicinity of Tallinn. Before the event, 317 artefacts had been collected in the vicinity, and at the end of the day, the best collectors were awarded prizes, accompanied with the orchestra. However, it is not known whether these objects were later received in the Estonian National Museum. Still, this event undoubtedly increased the awareness of people with regard to the value of antiquities. 
This was also the outset of the tradition of museum parties, aimed at introducing the work directions of the museum to the wider public. The first party, with a concert, dancing, lottery, sign-selling and other entertaining activities was organised by the Tallinn Department in the Estonia Theatre concert hall on 23 November 1918. The party was dedicated to the departure of the German occupying forces.

Now, when the dawn of our freedom is glimmering again, when every eye, be it young or old, is sparkling with hopes towards the future, now we also have to take care of our cultural institutions with all our efforts and eagerness. The Tallinn Department of the E. N. Museum, pushed into narrow frames because of external circumstances, as if pushed against the wall, is now intending to become a large and wide-based people's museum that could not only be recommended for the inhabitants of Tallinn, but also to neighbours and other nations. This is why the board of the museum department appeals to everyone with a request: do support the museum enterprise! (Päevaleht 22 Nov 1918)

In the same newspaper, the museum also presents its political manifest:

Our museum is people's museum and thus is open to all. The Museum stands aloof from all kind of politics and party activities, being thus on totally unbiased ground. This is why we dare to appeal to everyone with the request - to contribute to the museum undertakings as much as you can, according to your capabilities. Let us utilise our freedom to primarily fulfil our duty with regard to the museum! (Päevaleht 22 Nov 1918)

Buoyant efforts were made to procure larger premises for the museum. As one of the options, the possibility of using Kadriorg Palace was again discussed in the agenda, as evidenced in the minutes of the ENM Tallinn Department of 28 November 1918, at the meeting held in the brothers Parikas' place: With regard to the department's apartment, a decision is made to apply to the local town government, bearing in mind the Kadriorg Palace. (Minutes 15/1918)

At the end of the year, however, the museum was hit by burglars - the activities of the museum must have been too conspicuous, and confusing times are always a good season for smaller and larger crimes and thieves. A wooden box had been broken open in the museum corridor, and 1,331 postcards, recently sent from Leipzig, had all been taken. Some of these postcards, titled Jägala kosk Jõelähtmes ('Jägala waterfall in Jõelähtme') and Sõrulased rukist õsumas ('Sõru people harvesting rye'), were obtained back later - the police had caught two young boys with 420 postcards, and a Defence League member, Reikop, had bought 171 at the flea-market, paying one mark per a hundred 
cards. ${ }^{6}$ The museum was broken into on the night of 8 December, padlocks were broken, the doors tampered with and the drawers forced open. The loss was 308 marks and 60 pence of the money raised with the lottery, and the money for the postcards of Tartu, altogether 100 marks, and the silver coins of the parish court from 1828, the personal property of secretary A. Pulst (Minutes 16/1918).

After the end of the German occupation, the museum decided to immediately start collecting any war related material for the relevant military department. Negotiations commenced with the Supplies Management of the Estonian Army (Minutes 16/1918). Things went smoothly and during the first board meeting of 1919 , it was decided to:

assume the task of organising the Museum of the War of Independence, proposed by colonel Soots, chief of the operational staff. As the first stage, to open a military section at the ENM Tallinn Department. (Minutes 1/ 1919)

Information about this decision spread fast, particularly among the military, and number of soldiers' associations expressed their will to organise fundraising parties for the benefit of the museum (Minutes 11/1919 \& Minutes 13/1919).

\section{CONCLUSION OF THE FIRST YEAR OF OPERATION}

The first year of activity of the Tallinn Department of the Estonian National Museum was summarised during the first general assembly meeting of 1919. In his speech, Kristjan Raud underlined the circumstances and conditions the museum department had to operate under during the first year, and revealed the plans for the future:

The Museum Department has fortunately survived the difficulties of the German occupation, although the times were a substantial obstacle for the work and activity of the museum. At present, being protected by the government of free Estonia, and taking the position of being entitled to support, the Museum Department hopes to continue, more fruitfully, with the rescue of our heritage. The tower of Kik in di Kök has been chosen as more spacious and appropriate premises - and hopefully these rooms will be obtained for our disposal. The membership of the museum had significantly grown in Tallinn. (Protokoll I)

In 1915, the membership of the Tallinn Museum was 61; on 12 May 1918 - 191 persons and on 1 January 1919 - 379. The number of visitors in 1918 was 855 . 
Four parties were held for the benefit of the Museum Department: in Haapsalu, Hageri, Harku and Tallinn, the latter, being the most successful one, was organised by the Museum Department itself. Money was raised from parties, donations, membership fees and the sales of printed matter. With regard to the future, plans were made to supplement the existing collections with those of natural sciences. Yet as the first step, attempts were made to complete the collection of tangible heritage ${ }^{7}$ (Protokoll I). Still, there was probably no clear and explicit understanding as to when to consider a heritage collection completed and heave a sigh of relief. During the meeting, certain misunderstandings could be noted between the Tallinn Department, and E. Eisenschmidt, the representative of the ENM. The Rules of Procedure, devised by the Tallinn Department pursuant to the procedural rules adopted on 14 June 1918, were discussed during the meeting. Namely, K. Saral made a proposal that the ENM could allocate a subsidy for the Tallinn Department to purchase antiquities. The current Rules of Procedure had not provided for this issue. Eisenschmidt claimed that in the name of the ENM, he was not entitled to promise any financial support for Tallinn. Saral and Raud were of the opinion that a certain annual support sum should indeed be agreed upon, to be granted to the Tallinn Department on a yearly basis. The question remained unresolved, although a decision was made to add 10,000 marks, as expenditure, to the budget, hoping to receive this from the Estonian National Museum. The Tallinn Department felt too oppressed by the ENM, there were misunderstandings with regard to the number of board members, and a protest against the fact that the Tallinn Department should organise separate collections, exhibitions, parties, etc. only upon the relevant agreement of the Estonian National Museum. K. Saral claimed that pursuant to clause 7 of the Rules of Procedure, Kr. Raud was also the representative of the ENM in Tallinn, and thus free to approve any undertaken activities. Kr. Raud, on the other hand, expressed an opinion that if they had to ask for permission from the ENM for any minor activity, this would definitely impede the operation and undertakings of the Tallinn Department, and if this is not done, it would mean the violation of rules. In addition, the distribution of collection regions was one of the reasons for disagreement. Eisenschmidt's suggestion to be limited merely to the vicinity of Tallinn was not approved. Although this was to do with the one and the same Estonian National Museum, competition was clearly discernible when dividing the lines of force. Tartu people reproached Tallinn for collecting antiquities in Pärnu area, this accusation was countered by the Tallinn Department, noting that the Pärnu region had been totally neglected by the museum. Similarly, differences of opinion were also in the air with regard to the entrance fee. Tallinn wished to introduce a fixed sum, yet Eisenschmidt was firmly convinced that 
this would be inappropriate for the museum, and that voluntary donations would bring in more money that a fixed charge. Thus, the first dissent between Tartu and Tallinn was clearly visible (Protokoll I).

During the board meeting in May, held at the brothers Parikas', separatist moods did not yet prevail, although there were problems with self-discipline, and a decision was made to react to this:

Members of the board who are more than five minutes late to the meeting, and also those who are absent from the meeting without prior notice or reasonable excuse, shall be fined with 3 marks to go to the revenue of the Museum. (Minutes 10/1919)

Again and again, the premises remained to be the main concern. After long and complicated negotiations to rent the rooms in Kiek in de Kök tower, the idea was finally given up due to the smallness of the premises and expensive refurbishing that needed to have been done. With an aim to have new, more appropriate rooms, it was decided to gather more data about the Üxküll House at Toompea Hill, Tallinn Club and the Guild Hall at Pikk Street (Minutes 5/ 1919). Still, the palace in Kadriorg continued to be the best possible option (Minutes 18/1919).

\section{TOWARDS BECOMING AN INDEPENDENT MUSEUM}

For the first time, independence was discussed at the board meeting of the Tallinn Department on 5 July 1919, in the Ministry of Education, with the presence of Kr. Raud, K. Jürgenson, P. Parikas and A. Pulst, bearing in mind the great plans for future:

It is admitted to be necessary to explain the Museum idea at teacher training courses, to get local forces to work for the Museum, to arrange parties for the benefit of the Museum, to hire permanent - with a fixed salary-collectors and organise local exhibitions of collected antiquities; to give detailed suggestions and instructions in newspapers for collectors, and to publish lengthier campaigning articles in all newspapers in order to encourage collection. (Minutes 16/1919)

Likewise, the issue concerning the heritage collection was prioritised also at the next board meeting, dedicated solely to this aim, and a decision was adopted to start sending pairs of schoolchildren and social figures on collection trips. The areas chosen for this work comprised the vicinity of Haapsalu and the islands, as the losses of antiquities in these regions were most substantial, due 
to holiday-makers and buyers. For instance, the collectors on Muhu island had noted that the local people would not sell woollen garments for money, at any condition, however, they would exchange these clothes with purchasers and dealers for different haberdashery goods -

this way, one purchaser had collected 200 pairs of mittens, with an intention to un-weave them and have them knitted as new market goods. As there is no other good way out, the board is also going to switch to the exchange of goods. The total of 1,500 marks of credit is allowed in order to purchase a certain amount of goods to be exchanged. (Minutes 28/ 1919)

When discussing the issue of an independent museum, consideration was given to the fact as to what kind of impetus and freshness could the launch of the new museum bring about for collection endeavours, and whether a new independent museum could be an impediment in having complete ethnological collections in Tartu (Minutes 17/1919). Collection activities in Tartu had come to a standstill, and this was the main argument for Kr. Raud why the Tallinn Department should become a separate and independent museum.

One of the ideas, with an immediate impact on the work of the Tallinn Department, was the establishment of an open-air museum. In his memoirs, August Pulst writes that he had made a proposal to the board, at the very beginning of its operation, to launch an open-air museum. Together with $\mathrm{Kr}$. Raud, they had visited the Seurasaari Open-Air Museum in Finland in 1916, and this had left a wonderful impression on them. With T. Künnapuu, his schoolmate, they had found a suitable plot at the River Pirita, in Lükati. Pulst, arguing in favour of his proposal, stated that the Estonian National Museum in Tartu had been actively involved in searching for possibilities for an openair museum, but Tallinn was a much larger city than Tartu! (Pulst 1973: 16) Thus, at the board meeting on 5 July 1919, a decision was made to establish such a museum. An outing-trip was arranged at the beginning of September to find a suitable location, the relevant committee comprised Kr. Raud, K. Jürgenson, Paul Raud, Dr. A. Lüüs, instructor Johanson, A. Tabbur and A. Pulst. The first stop was in Kose forest (Koch Park), on the left bank of the River Pirita, to have a look at the surroundings, up to approx. half a mile upstream from the river-mouth. The impression was indeed very positive. The second potential site, 7 miles away from Tallinn, was near Lükati, ca 1.5 miles inland towards the seashore. The conclusion was as follows:

When comparing Lükati and Kose areas, the committee considers the former to be much more appropriate, and bearing in mind the plans of the local town government, to build a zoo and a sanatorium in Lükati, 
which would assumedly mean that there will be an electric railway connection with this area, the committee puts the Lükati area in first place, as a location for an open-ait museum. The final decision will not be made until all the potentially suitable locations in the vicinity of Tallinn have been studied. (Minutes 23/1919)

The next outing to find a proper place for the open-air museum was proposed by architect K. Burmann, and headed to Haabersti and Rocca al Mare, together with Kr. Raud, J. Lintrop, A. Laikmaa, K. Burmann and A. Pulst. The trip was high-spirited, and as a result, the committee adopted a decision to consider the particular location appropriate for the establishment of an openair museum (Minutes 26/1919).

The idea of an independent museum in Tallinn was continuously growing. In the autumn of 1919, plans for future were discussed at several board meetings in Tallinn, where the thought of an independent museum was repeatedly reverberated. There was also an option in the agenda of a central museum to be located in Tallinn, with departments in all towns (Minutes 24 \& 25/1919). During the discussion on 4 October, Karl Jürgenson highlighted the following points in regarding this plan: 1) it is easier to do promotion in Tallinn; 2) the new society would bring in new material; 3 ) with its museum department, Tallinn is as if of a second category; 4) negotiations with Tartu are an impediment in carrying the things forward. Still, Jürgenson admitted that the preparatory potential was better in Tartu, due to the university, and there were no properly qualified personnel in Tallinn. ${ }^{8}$ (Minutes 25/1919) Long and passionate discussions were held, mainly whether to form one large or several small museums, whereas the aim of the museum was primarily seen as heritage collection, and proceeding from this - which of the two variants would facilitate the collection of more antiquities in all parts of Estonia - in Setomaa in the south-east and Saaremaa island in the west. According to Kr. Raud, the 10 years of operation of the Estonian National Museum had actually been a relatively long period for the museum to become outdated - it is important to rescue the antiquities, making gigantic efforts in this regard. P. Parikas continued to be in favour of having several museums, and said that the main drawback of the Tartu museum was the fact that the communication between board members was complicated as the latter were scattered in a number of different towns. A. Pulst, on the other hand, fervently opposed the idea of having the state in charge of the organisation of heritage collection:

If the government steps ahead, the people would pull off their hands... In Pärnu area, people were afraid of showing old things, thinking these would be registered and taken away later on. The parson in Mihkli did not want 
give permission to the representative of the museum to look around in the church, for the same reasons, and said that the government could also confiscate the properties of the church, and it is therefore necessary to be cautious. (Minutes 25/1919)

K. Jürgenson, holding a totally different standpoint, claimed that a museum of a social circle is a cottar's museum, and money is the basis of everything. If the government gives money for the collection of artefacts, everything will be collected. H. Vaks proposed that all museums should be convened under a uniform central organisation which would then make proposals to the government, as in the case of the Association of Estonian Actors. This central organisation would also be competent to place and locate individual collections; or in other words, to establish an independent museum in the capital, disregarding everyone. K. Jürgenson was most adamant in demanding to devise a collection plan with the help of the government: to set up a collection working group, organise training courses for collectors, apply for credit and appoint a consulting representative at the Ministry of Education. ${ }^{9}$ A resolution was adopted wherein clause 1 states as follows:

a) As there is no Estonian Museum or a relevant society in Tallinn that could bring this into life, and as the operation of the Tallinn Department of the E. N. Museum (heritage collection working group) is too limited for the foundation of such [an institution], the board of the Museum Department shall consider it appropriate to establish an independent museum in Tallinn.

b) In principle, the board shall confirm that the central museum be founded in Tallinn, departments shall be launched in county towns, where there is no museum yet, bearing in mind the rapid loss of antiquities and urgent need to rescue these, and

d) The board is of the opinion that governmental support to the functioning of museums is strenuously needed, both with regard to material support, and also to maintain an expedient balance between individual museums of Estonia. (Minutes 25/1919)

The extraordinary meeting of the Tallinn Department, on 14 November 1919, adopted the resolution:

The capital demands an independent museum for comprehensive presentation of the land and people. At the same time, there is also a need in Estonia for another type of large-scale museum that would enable the investigation of the domains that have been more left aside in the operation of the Estonian National Museum. It would be impossible in the 
future to widen the scope of the museum in Tallinn, as the Department of the Estonian National Museum, bearing in mind the impeding dependence of the Department from Tartu. For this reason, the meeting has decided to [...] terminate the operation of the E.N.M's Tallinn Department. (Minutes 30/1919)

The former collections of the Tallinn Department of the Estonian National Museum were stored in the Estonian Museum Society, and remained in the ownership of the Estonian National Museum. The liquidation committee comprised August Pulst and Bernhard Linde (Minutes 30/1919).

With an aim to establish the Estonian Museum in Tallinn, eight preliminary meetings were held from 5 October to 9 November 1919, participated in by Kr. Raud, K. Jürgenson, A. Thomson, P. Parikas, H. Vaks, A. Pulst and J. Vestholm. The statutes of the Estonian Museum Society were devised and legally registered in the Tallinn-Haapsalu Peace Court on 7 November 1919. The aim of the Society was to establish and maintain the Estonian Museum in Tallinn. The purpose of the Estonian Museum was to promote the knowledge of Estonian people and the country, by way of cultural-history, ethnographic and natural science collections. The more immediate task was to rescue heritage all across the country, with a relevant budget of 940,000 marks, with 15 collectors and 10,000 artefacts.

The opening meeting of the new Estonian Museum Society took place on 17 November; in the beginning, there were 23 members of whom $\mathrm{Kr}$. Raud, K. Jürgenson, P. Parikas, A. Thomson and A. Pulst were elected as board members. Indeed, 17th of November 1919 is considered the commencement of the Society and the Estonian Museum.

Raud, Jürgenson and Pulst, the members elected at this general meeting, announced in Tartu, on 30 November, at the general meeting of the Estonian National Museum, that they had established a new museum in Tallinn, the "Estonian Museum in Tallinn", and suspended the operation of the Tallinn Department of the E.N. Museum. Should the E. N. Museum wish so, they can continue with the work of the department. The representative of Tallinn disclosed that the new museum - Estonian Museum in Tallinn, has set up a plan to collect heritage all over the country. The E.N. Museum responds that they would like to take part in this. (Pulst 1973: 21)

The meeting to settle the relationships between the museums took place on 3 January 1920, with the presence of E. Eisenschmidt and Gustav Matto on behalf of the ENM, and Kr. Raud and K. Jürgenson from the Estonian Museum in Tallinn. Following lengthy discussions as to what would remain in Tartu 
and what in Tallinn, the atmosphere being oppositional, with no hint of friendly cooperation, it was finally decided:

1. ...The Estonian Museum Society in Tallinn shall give the more rare objects of its ethnological and archaeological collections to the Estonian National Museum, to supplement their collections, and shall receive doublets from them.

2. The Tallinn Department of the E.N.M shall be terminated pursuant to the decision made by the general assembly of the E.N. Museum and its active members on 30 Nov 1919.

3. All the collections and property gathered at the Tallinn Department of the E.N.M, until the day of liquidation, shall be in the ownership of the E.N. Museum.

4. From these collections and property, the E.N. Museum shall give the Tallinn Museum Society [the right to]:

a) use of the fittings of the department;

b) for permanent storage, the collections that have been given to the department on condition that these would stay in Tallinn, and doublets from other collections.

5. The E.N. Museum shall agree to leave the government subsidy $(72,500$ marks) to the T.E. Museum Society, upon relevant possibilities. Otherwise, the department shall utilise the money to purchase things which, as the property of the E.N. Museum, shall be left with the Tl. E. Museum.

6. The objects of private persons and institutions, stored at the Department of the E.N. Museum, shall be kept at the Tl.E.M. Society under the same conditions. (Pulst 1973: 21-22)

Thus, the collection endeavours commenced vigorously in 1920, and courses on the collection of tangible heritage were organised, $\mathrm{Kr}$. Raud lectured on theory, Karl Burman on Estonian buildings, Matthias Johann Eisen introduced the collection of verbal and linguistic heritage, Peeter Süda focused on the collection of folk tunes, and Peeter Parikas on photography. At the end of the course, there was a demonstration of antiquities and a trip to the ENM, followed by practical work in town and countryside (Course programme). In 1920, the Ministry of Education began to contribute to collection activities, and arranged the countrywide rescue days of antiquities on the 9th and 10th of May, when teachers and students of rural schools were obliged to go and collect ethnographic and cultural history related heritage for museums, and not be involved in studying. There were 34 paid collectors in 1920, their number decreased as of 1922 and reduced to none in 1924 (Paas 2004). 


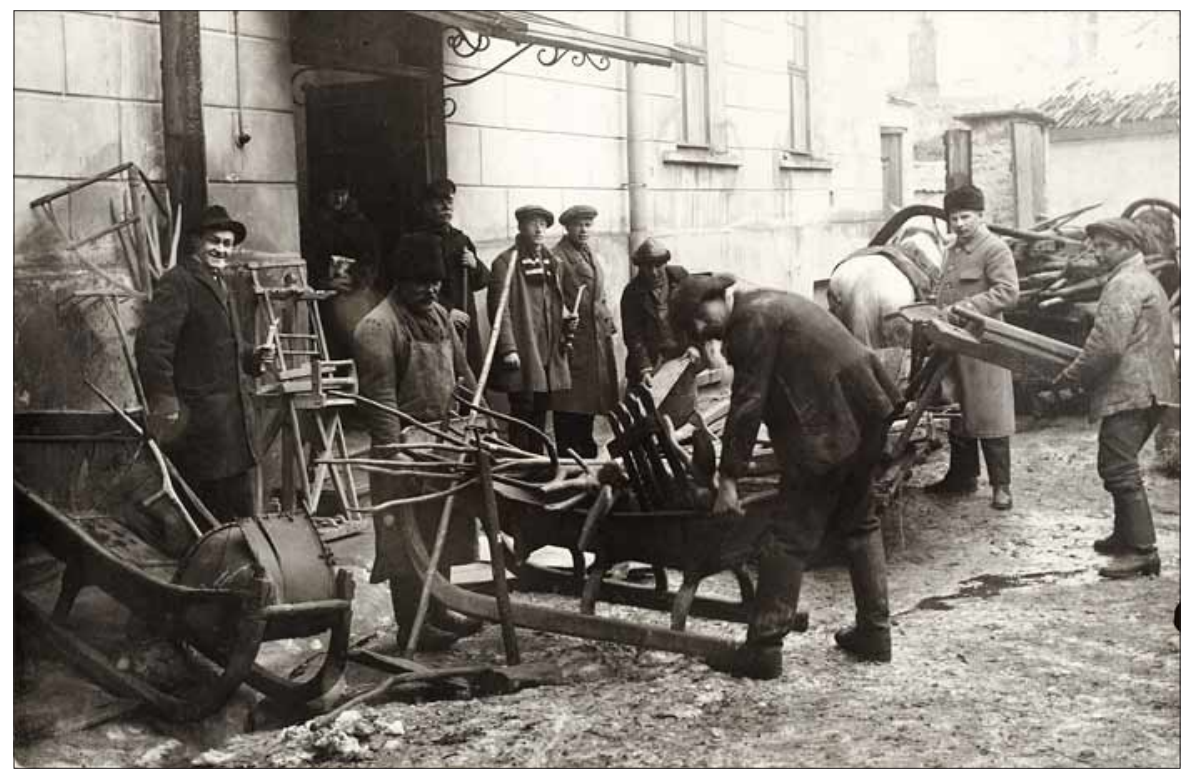

Figure 2. The Estonian Museum in Tallinn moving from the former Knighthood House on Toompea Hill to the Kadriorg Palace (from the yard) 1921. Second from the left: August Pulst. ERM Fk 1706:21. Photo by Johan Wildt.

Expanding collections again exacerbated the issue regarding insufficient space. The rooms at the disposal of the museum in the Estonia Theatre building, and the coat of arms hall in the Knighthood House could not accommodate the large amount of artefacts, let alone display them. Thus, the museum appealed to the Ministry of Education to obtain the right to use the Kadriorg Palace. However, the ministry was also interested in the palace; the building, ravished in war, was at the time being laid out for the national art museum. As the Ministry of Education's collection of Estonian art, applied art and styled furniture was still small, Kr. Raud who worked at the time in the ministry, in the department of art and antiquities, made a proposal to give the entire palace to the art museum, and while they were not yet able to fill all the rooms, to allow the Estonian Museum in Tallinn to set up its collections there. The government of the Republic of Estonia approved this proposal (Paas 2004).

When establishing the museum in Tallinn, the intention was to go along exactly the same path as the Estonian National Museum in Tartu, and to continue with what had already been done earlier, as the department of the ENM. This was a situation where there were two parallel ethnographic museums operating in Estonia, and no museum of fine arts whatsoever. 


\section{CHANGE OF DIRECTION}

The moving of the museum to Kadriorg Palace was a step forward in the change of course. In 1919, August Weizenberg, the sculptor, who had returned to his homeland to spend his retirement days, had been granted permission from the Construction Board, the then owner of the Kadriorg Palace, to place his figures, and the ones he had sold to the town, in the palace (Paas 2004). The Estonian Museum in Tallinn had managed to procure quite a few works of art, imported from Russia, a substantial addition to the museum's art collections (Linde 1931: 10). Gradually, the collections of the museum increased because of the many heritage collectors who brought back, from their expeditions, the objects and artefacts that had belonged to churches and manors. The festive opening of the museum in the Kadriorg Palace took place on 10 September 1921, during the agricultural exhibition. When the exhibition ended, the Estonian Museum also closed its doors, and persons involved began to expand the display and prepare the work in a better well-thought out manner.

At the same time, impetuous heritage collection continued, with an intention to complete this in 1921. The task force for the rescue of Estonian heritage finished its work on 21 April 1921, but the collection was continued directly under the auspices of the Estonian Museum in Tallinn (Pulst 1973: 4142). In addition to the collection of ethnographic artefacts, attempts were made to find opportunities to establish an open-air museum. Unfortunately, there were several unsuccessful endeavours to obtain land from the town government, whereas the artefacts in the country had already been selected for removal, among them the old wooden church on Ruhnu island. August Pulst went to conclude a deal with the islanders, having previously received the Ruhnu inhabitants in Tallinn and showing them around. As a reward, he was welcomed on Ruhnu as a friend. The islanders agreed to transfer the church, built in 1644, to the museum, they even consented to break it down, take it to the shore and load it on the ship, but in return they wanted an organ for the new church, at an approximate price of 70,000 marks. From this trip, Pulst brought back nearly 200 artefacts, mainly meant to furnish the "Ruhnu room" in the museum (Postimees 25 Aug 1921).

The tradition of museum parties was maintained, upon the initiative of A. Pulst whose interest in folk music was a great connecting element between people and merrymaking festivities. He had been involved in amateur theatremaking during his collection expeditions for the Estonian National Museum. At that time, there were no strict rules for handling museum objects, and people were happy to put on the collected folk costumes and play theatrically to entertain themselves and the others. Pulst writes in his memoirs about a festivity in Raiküla in 1920: 
The hall was filled with spectators, explanations given by the collector and myself. In the same community house, the party room was filled to the brim. In the programme: songs by the mixed choir of Raiküla and a play. (Pulst 1973: 31-32)

No doubt, these events were profitable, making the public aware of the value of heritage and the essence of the museum.

The museum was continuously expanding - in January 1922, a memorial room for Peeter Süda was opened, furbished with the possessions of the composer, donated by the heirs (Paas 2004).

In 1924 , the museum continued to grow, with a focus on the collection of folk dances, folk games and relevant music. In the same year there was a significant impetus for the museum, to open the department of fine arts in an accelerated manner: the Ministry of Education and the Tallinn Town Government deposited a large collection of newer Estonian art, to be stored and displayed in the museum (Linde 1931: 13).

1925 was pivotal for the museum with regard to the change of course earlier diffusion and the creation of new departments, i.e. fragmentation was replaced with consolidation and focusing, by putting two domains in the forefront: the department of fine arts and the collections of cultural history related heritage, as the ones deserving most attention, were arranged for display (Linde 1931: 13).

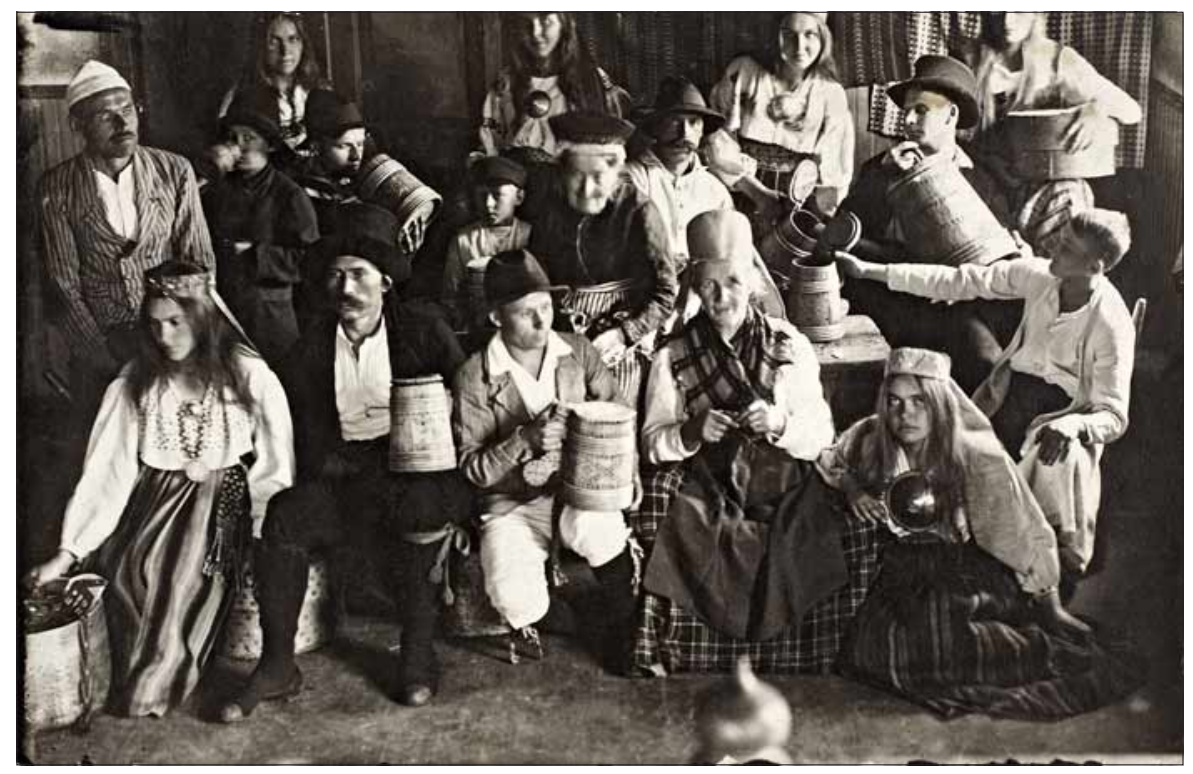

Figure 3. Participants in the Raiküla party, arranged by the Estonian Museum in Tallinn. 1920. ERM Fk 1706:18. Photo: unknown. 
Still, the existence of two similar museums, in Tartu and in Tallinn, was senseless for a small country, and the formation of an art museum was of great significance for a nation state. Thus the relevant step was in every way a logical result of earlier developments.

Nearly the whole of the homeland had by now been covered with collection trips, and thus the five-years-long operation of the Estonian $\mathrm{Mu}$ seum in Tallinn has come to an end. Should there still be two museums working adjacently in Tallinn and Tartu, both mainly the collectors and keepers of ethnographic objects? Considering the small size of our homeland, such a superfluity would be clear for even a casual observer. Thus, gradually a standpoint was reached that the Tartu-based Estonian National Museum should be ethnographic and the museum in Tallinn - an art museum. (Linde 1931: 14)

From today's viewpoint, it is weird and even comical as to how certain limits were set for having collected the heritage. Yet at the time, there was some truth in this as large-scale collections had been completed and the collections of both museums had been continuously growing. The line had to be drawn somewhere. Increased costs related to ethnographic collections were undoubtedly another considerable reason for such a standpoint.

The process of how the Estonian Museum in Tallinn gradually evolved, from an ethnographic museum to an art museum, can be observed on the basis of published catalogues. When comparing the years 1922 and 1923, art collection had obtained an additional room; in 1927, the folk art department displayed a representative exhibition (Estonian Museum in Tallinn 1922; Estonian Museum in Tallinn 1923; Tallinn Museum 1927).

Following lengthy discussions, there was the moment, on 22 November, when the extraordinary general assembly of the Estonian Museum Society in Tallinn decided to amend the statues and develop the Estonian Museum into an art museum (Paas 2004). With this, the change of direction was completed and the development of the art museum commenced.

Estonian artists and intellectuals had been striving for an art museum for a number of years. However, this plan had receded into the background due to the powerful performance of the Estonian National Museum, and the goals and purpose of the ENM had been more explicit and understandable for the wider public. Rendering value to ethnic nationality, history and folk culture this was an undisputable domain. The discussions, whether the Estonian National Museum should collect Estonian art did take place as early as during the foundation meeting of the ENM, however, these disputes were finally overshadowed by antiquities and the library. At the time, Jaan Tõnisson was the 
person who stood up for art collections. The issue concerning art was explicitly raised in connection with the III Exhibition of Estonian Art in 1910. In the promotion address of the exhibition, Tõnisson writes, among other matters:

On their behalf, the authorised working group expresses the idea to purchase works of art, for pure profit, for the Estonian National Museum in Tartu and for the Museum of Art to be established in Tallinn. Should this application by the working group be accepted, it will be the jury of the art exhibition who will decide as to what works to buy. (Promotion address 1910)

In reality, due to the more than limited financial circumstances, it was even impossible to think, more seriously, about a separate museum for Estonian art. Instead, the only option to be considered was to establish a department of fine arts at the Estonian National Museum. This was indeed the platform taken by the artists involved in Noor-Eesti (literally: Young Estonia), the cultural movement of the young intelligentsia, and by those interested in art; they also decided to demand, from the leading forces of the Estonian National Museum, to be given some independence at the department of fine arts formed in the ethnographic museum (Linde 1931: 6-7).

The possibilities to collect art were discussed at the beginning of 1911, during the meeting convening active members and the board. According to Oskar Kallas, there were no financial resources at their disposal to purchase art, at least in the beginning, as the only revenue of the ENM Society were membership fees and donations, used solely for obtaining antiquities. The collection of works of art would have been possible only in the form of donations and deposits. Likewise, it was important to display art and give the artists a much needed opportunity to sell their works.

At the least, what we need to create, is a site for a permanent art exhibition, where the artists, scattered around the world, could keep their work, and where their works could be bought, etc. (Minutes I: 27-28)

A decision was adopted during the same meeting, to form a working group with a task to make proposals for devising the collection, organise exhibitions and promote fine arts. The board members suggested the body of active members to elect a working group where the majority of persons would be in favour of modern art. However, as the attitude towards modern art, in the view of those involved in the Postimees newspaper, was hostile and narrow-minded, and the ENM was closely connected with these people, there were strong disagreements regarding the membership of the working group on art (Hinnov 1984: 11-12). 
Two months later, when commencing with the election of the members for the working group on art, the majority of the proposed persons, and wholehearted supporters of modern art - Bernhard Linde, Dr. Juhan Luiga, Friedrich von Stryk and Karl Menning - were left out. Thus, the intention to collect Estonian modern art failed due to the strong influence of the gentlemen in the Postimees newspaper. Thus, Kr. Raud, K. Burmann and Adolf Luiga, a student of the law faculty, were elected in the working group, and also Karl August Hindrey, a man with a suspicious attitude towards modern art movements, and Paul Raud and August Jansen, an art student in St. Petersburg, who represented academic art (Minutes I: 33). According to existing data, this was the first meeting when the establishment of an Estonian art museum was discussed, with the venue and initiators in Tartu (Linde 1931: 7). Unfortunately, the initial plans - to collect and promote modern Estonian art - were not implemented. The working group on art was the weakest of all the workgroups operating at the time in the Estonian National Museum, and was in no position to develop into an independent contemporary art museum.

The transfer of the ethnographic objects of the Estonian Museum in Tallinn, to the Estonian National Museum in Tartu, was a long and complicated process. Negotiations were launched between the museums in Tallinn and Tartu, concerning the possibility of exchanging the artefacts, whereas both these institutions wished to maintain a representative collection - the Estonian Museum in Tallinn wanted to preserve an ethnographic collection, and the Estonian National Museum intended to keep an art collection. According to Linde, longlasting negotiations failed due to the inflexibility of Tartu, as the ENM did not want to surrender the works of art kept in the museum (Linde 1931: 15). The relevant negotiations about the transfer of artefacts to the ENM commenced in 1926 and continued in 1936 and 1941.

\section{CONCLUSION}

Since the foundation thereof, the Estonian National Museum sustained and is still sustaining the idea of collecting, keeping and promoting the culture of Estonian people. Among a number of different domains, folk culture has always been the priority. The first decades of the 20th century have secured the place in history as the period of large-scale heritage collection. Kristjan Raud, the main ideologist of these collection campaigns, has written about this in a passionate manner: 
We will not be silent, we will not be tired until every child in a village knows what the Museum is about, and until every farmstead has given their antiquities to the Museum. (Raud 1911)

This was the beginning of a major museum boom, the ideology of which was to find something from our past to be proud of, to search for the roots and the desire to prove to the whole world that Estonians, too, are a nation of culture.

In this article, I attempted to show that these ideas were also cherished by the Estonian National Museum in Tartu, and its department in Tallinn, which developed into the Estonian Museum Society in Tallinn, and thereafter, into the today's Art Museum of Estonia.

As it is always the case in history, a lot depends on individuals. Kristjan Raud was one of the key figures of this process; being an artist, he was passionate about heritage, and had initiated the collection of artefacts, for the Learned Estonian Society, as early as at the beginning of the 20 th century. Raud was a wonderful organiser of collection endeavours, when in charge of the heritage collection working group of the Estonian National Museum, and later, as the chairman of the board of the Estonian Museum in Tallinn. Kr. Raud was an ideologist, A. Pulst, on the other hand, was an active hands-on person. Behind them was the ever growing and activating Tallinn-based membership of the ENM. The uniting force for these people was to rescue antiquities, to honour and praise their national culture, and by doing so, render value to the past. Indeed, one of the most important reasons, for the Tallinn Department to develop into a separate museum, was their aim to better organise heritage collection - to rescue the artefacts and folk culture. The relevant activities of the Estonian National Museum in Tartu had been more modest in war-time.

There is nothing surprising in the fact that the Tallinn Department of the Estonian National Museum became a competitor for the "parent museum". This is a natural course of events when two institutions are targeted towards the same direction. Competition is a constructive force and facilitates a better outcome. There is no doubt that Estonian cultural heritage has gained from this competition. The fact that A. Pulst could not send his Tori collection to Tartu, and had to instead take the artefacts to Tallinn, is not a reason for the emergence of a new museum, it is rather an impetus that launched the process. A national art museum and a museum reflecting folk culture are the two substantial pillars upholding the cultural history of a nation, regardless of the fact how these museums are named in different countries. The third large museum is usually the history museum, expressing the historical-political memory.

I was inspired to write the article in order to ascertain how the Tallinn Department of the Estonian National Museum developed. During the first 
years of the Republic of Estonia, folk culture was highly cherished, and seen as the source of motivation and inspiration for our artists. However, along with the development and participation in world culture, this direction gradually faded into the background. National romanticism had become outdated. The vast majority of the individuals, who were actively involved in museums and heritage collection at the time, have made their way to our cultural history primarily as artists.

In conclusion, it can be stated that thanks to these people and the two museums, we have a magnificent collection of Estonian folk culture which hopefully underlines the viability of our culture and will inspire artists during the forthcoming centuries, irrespective of fashionable trends. The Art Museum of Estonia should not be ashamed for being conceived from the Estonian National Museum.

\section{NOTES}

${ }^{1}$ Hereinafter referred to as the Estonian Museum in Tallinn (Tallinna Eesti Muuseum), this is also the most prevalently used name form of the institution.

${ }^{2}$ In 2009, the Estonian National Museum celebrated its 100th anniversary in Tartu, and the Estonian Art Museum marked the 90th birthday in Tallinn.

3 August Pulst was born to a farmer's family, on 14 January 1889, in Pärnu County, Tammiste rural municipality. He died on 22 November 1977 in Tallinn. Pulst graduated from the pro-gymnasium of the Estonian School Society in 1908, studied painting in the Art School of Riga during 1911-1915 and obtained a qualification as an art teacher. His supervisor was academician Vilhelms Purvitis. During 1915-1917, Pulst worked as a stage painter in the Estonian Theatre, participated in the establishment of the Tallinn Department of the ENM in 1916 and in founding the Estonian Open-Air Museum in 1926 (worked as a chairman in 1931). During 1919-1926 he worked as the secretary of the Estonian Museum in Tallinn, during 1932-1937 as a clerk in the Estonian Music Museum, and as the head of the Music Museum 19371944, and as a senior researcher in the Estonian Theatre and Music Museum 19441946.

${ }^{4}$ Tallinna Kaja No. 46, 21.11. (4. 12) 1915. pp. 721-736

${ }^{5}$ Number of Russian-language revolution related books - 167, brochures in Russian 178, communistic brochures in Russian - 241, Estonian language brochures - 302 . Altogether 1,557 copies of archival material.

6 Both postcards were photographed by Johannes Pääsuke, the photographer of the ENM.

7347 artefacts and three paintings were obtained during the first year of operation: Laipmann's Landscape with a farmstead, August Jansen's Herding at night and Baldur Toomasberg's aquarelle Windmills on the island. In addition to artefacts, depositions included 17 paintings, four drawings and nearly 2,000 books and brochures. 
8 Actually, there were no qualified members of staff both in Tartu and in Tallinn. Helmi Reiman (Neggo) was the only employee in the ENM, during 1916-1917, who had studied ethnography at the University of Helsinki.

9 This was the time when the idea of creating the task force for the rescue of Estonian heritage (Eesti Muinasvara Päästetoimkond) was conceived.

\section{ABBREVIATIONS}

$\mathrm{ERM}=$ Estonian National Museum

ERMA = Archive of the Estonian National Museum

ERM EAV = Ethnographic Archive of the Estonian National Museum. Varia

ERM Fk = Photo collection of the Estonian National Museum

\section{ARCHIVAL SOURCES}

\section{The Archive of the Estonian National Museum}

Miscellaneous loose-leaf material of the Tallinn Department of the ENM 1919-1920. ERM inventory 1 , record 588:

Minutes of the board meeting of the Tallinn Department of the Estonian National Museum:

Minutes 5/1918 = Minutes No. 5, June 4, 1918

Minutes 6/1918 = Minutes No. 6, September 11,1918

Minutes 15/1918 = Minutes No. 15, November 28, 1918

Minutes 16/1918 = Minutes No. 16, December 18, 1918

Minutes 1/1919 = Minutes No. 1, February 3, 1919

Minutes 10/1919 = Minutes No. 10, May 13, 1919

Minutes 13/1919 = Minutes No. 13, May 30, 1919

Minutes 15/1919 = Minutes No. 15, June 5, 1919

Minutes 16/1919 = Minutes No. 16, July 5, 1919

Minutes 17/1919 = Minutes No. 17, July 30, 1919

Minutes 18/1910 = Minutes No. 18, August 4, 1919

Minutes 20/1919 = Minutes No. 20, August 20, 1919

Minutes 22/1919 = Minutes No. 22, August 28, 1919

Minutes 23/1919 = Minutes No. 23, September 6, 1919

Minutes 24/1919 = Minutes No. 24 (no date)

Minutes 25/1919 = Minutes No. 25, October 4, 1919

Minutes 26/1919 = Minutes No. 26 (no date)

Minutes 28/1919 = Minutes No. 28, October 28, 1919

Minutes 30/1919 = Minutes No. 30, November 12, 1919

Activity report = Eesti Rahva Muuseumi Tallinna Osakonna I. tegevuse aasta aruanne 12-st maist kuni 1-se jaanuarini 1919 "Estonia” teatri majas. [Activity Report of the 1st year of Operation of the Tallinn Department of the Estonian National Museum, from May 12 to January 1, 1919, in the Estonia Theatre building.] 
Course programme = Eesti Museumi Ühing Tallinnas 1920 a. Ainelise vanavara korjamise kursuste kava. [Estonian Museum Society in Tallinn. Course on the Collection of Tangible Heritage. Programme.]

Minutes I = Eesti Rahva Museumi" tegevliikmete kogu ja juhatuse protokollid 1909 kuni 1913. I. [Minutes of the general assemblies of active members and the board of the "Estonian National Museum" from 1909 to 1913.] ERMA inv. 1, r 8.

Minutes II = Eesti Rahva Museumi Protokolli-raamat II. Juhatuse ja üleüldiste liikmete ja tegevliikmete koosolekute protokollid. [Minutes-book of the Estonian National Museum II. Minutes of the general assemblies of the board, members and active members of the Estonian National Museum.] 03.02.1914 - 03.06.1918. ERMA inv. 1, r. 9

Protokoll I = Eesti Rahva Muuseumi Tallinna Osakonna peakoosoleku Protokoll nr I 11. mai 1919. [Minutes No. I of the 1st General Assembly of the Tallinn Department of the Estonian National Museum, May 11, 1919.]

Rules of Procedure = Eesti Rahva Muuseumi Tallinna Osakonna KODUKORD [Rules of Procedure of the Tallinn Department of the Estonian National Museum.]

\section{Ethnographic Archive of the Estonian National Museum. Varia}

Pulst 1973 = August Pulst 1973. Minu tööst seoses rahvakunsti - etnograafiaga. [About my Work in Connection with Folk Art - Ethnography.] Manuscript. ERM EAV 26. $102 \mathrm{pp}$.

\section{Archive of the Art Museum of Estonia}

Paas 2004 = Paas, Heini. Eesti Kunstimuuseumi ajaloost 1919-1944. [About the History of the Estonian Art Museum 1919-1944.] Manuscript.

Pulst $1948=$ August Pulst 22.09.1943 - 2.12. 1948. Eesti Muuseum Tallinnas. Ajaloolisi andmeid. Aug. Pulst. [Estonian Museum in Tallinn. Historical Data. Aug. Pulst.] Manuscript. 205pp.

\section{REFERENCES}

Estonian Museum in Tallinn 1922 = Eesti Muuseum Tallinnas. Ajutine nimestik. [Estonian Museum in Tallinn Temporary List of Records.] Tallinn, 16pp.

Estonian Museum in Tallinn 1923 = Eesti Muuseum Tallinnas. Ajutine kataloog. [Estonian Museum in Tallinn Temporary Catalogue.] Tallinn, 16pp.

Estonian National Museum 1918 = Eesti Rahva Museum 1916 ja 1917. Eesti Rahva Museumi väljaanne nr. 15. [Estonian National Museum 1916 and 1917. Publication of the Estonian National Museum No. 15.] Tartu.

Hinnov, Virve 1984. Eesti Rahva Muuseumi kunstikogu. [Art Collection of the Estonian National Museum.] Etnograafiamuuseumi aastaraamat XXXIV. [Yearbook of the Ethnographic Museum XXXIV.] Tallinn: Valgus, pp. 11-28. 
Leinbock, Ferdinand 1934. Eesti Rahva Muuseum 1909-1934. [Estonian National Museum 1909-1934.] Tartu: ERM Ar. IX/X.

Linde, Bernhard 1931. Eesti kunstimuuseumi mõtte areng ja Tallinna Eesti Muuseumi Ühing. The Evolvement of the Idea Concerning the Estonian Art Museum and the Estonian Museum Society in Tallinn.] Eesti Kunstimuuseumi aastaraamat I. [Yearbook of the Art Museum of Estonia I.] Tallinn: Tallinna Eesti Muuseumiühing, pp. 5-32.

Matto, Gustav 1916. Vanavara korjamine 1915. a. [Heritage Collection 1915.] Eesti Rahva Muuseum 1915. Eesti Rahva Museumi väljaanne nr. 12. [Estonian National Museum 1915. Publication of the Estonian National Museum No. 12.] Tartu.

Õnapuu, Piret 2006. Foreword. Vanavara kogumisretkedelt 2. August Pulst. [Heritage Collection Expeditions 2. August Pulst.] Tartu: Estonian National Museum, pp. $5-27$.

Õnapuu, Piret 2007. Eesti Rahva Muuseumi algaastate suurkogumised. [Large-scale Collection Campaigns during the First Years of the Estonian National Museum.] Eesti Rahva Muuseumi aastaraamat L. [Yearbook of the Estonian National Museum L.] Tartu: Estonian National Museum, pp. 11-42.

Õunapuu, Piret 2009. Tallinna Osakond. [The Tallinn Department.] Eesti Rahva Muuseumi 100 aastat. [100 Years of the Estonian National Museum.] Tartu: Estonian National Museum, pp. 96-99.

Paas, Heini 1980. ENSV Riikliku Kunstimuuseumi ajaloost. Muuseumi rajamisest ja tegevusest 1919-1940. Kogude teatmik. Artiklid 1979. [About the History of the State Art Museum of the Estonian SSR. The Establishment and Operation of the Museum 1919-1940.] Tallinn: Eesti NSV Kultuuriministeerium, Eesti NSV Riiklik Kunstimuuseum, pp. 31-41.

Päevaleht 22 Nov 1918 = Toetage Museumi ettevõtet - pidu! [Support the Museum Enterprise - Party!] Päevaleht newspaper No. 29.

Postimees 25 Aug 1921 = Muinasvara Ruhnu saarelt. [Antiquities from Ruhnu island.] Postimees newspaper No. 191.

Promotion address $1910=$ Eesti III kunstinäituse üleskutse 1910. [Promotion address for the III Exhibition of Estonian Art.] Päevaleht newspaper No. 64, March 19.

Pulst, August 1915a. Eesti rahwa riided ja kirjad (mustrid). [Estonian Folk Costumes and Patterns.] Päewaleht newspaper No. 239, October 17.

Pulst August 1915b Meie esivanemate mälestused. [The Memories of our Ancestors.] Tallinna Kaja, No. 46, 21.11. (4.12), pp. 721-736.

Raud, Kristjan 1911. Eesti Rahva Museumi lill. [Flower of the Estonian National Museum.] Postimees newspaper No. 182, August 16.

Tallinn Museum 1927 = Tallinna Muuseumi ajutine kataloog. Tallinn Jaanuar 1927. [Temporary Catalogue of the Museum in Tallinn. January 1927.] 32pp. 